
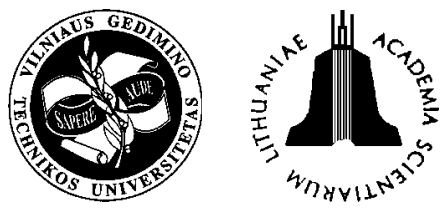

ISSN 1648-4142 TRANSPORT

\title{
EVALUATION OF THE COMPETITIVENESS OF THE SYSTEM OF PASSENGER TRANSPORTATION BY RAILWAY
}

\author{
Algis Žvirblis ${ }^{1}$, Jonas Butkevičius ${ }^{2}$ \\ Dept of Transport Management, Vilnius Gediminas Technical University,

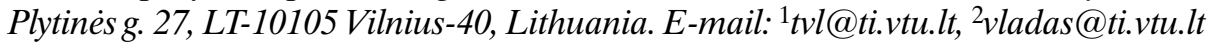

Received 2004-02-01, accepted 2004-04-15

\begin{abstract}
Considering the impact of technological factors on the system of passenger transportation, the emphasis is placed on competitiveness as a criteria of evaluation the efficiency of its performance. The system of passenger carriage by railway is analysed in terms of an automatic control system.

An algorithm for constructing a formalized competitiveness model is provided defining local competitive abilities in respect to the units of a technological complex including the component of infrastructure determined by its state and the admissible speed and the component referring to rolling stocks.

Thorough examination of the routes based on the methods offered in this work is needed to make proper decisions about their efficiency. A number of actions which should be taken to largely improve passenger carriage by railway is also described.
\end{abstract}

Keywords: system of passenger carriage, railway transport, competitive ability, technological factors, infrastructure, rolling stock, amissible speed.

\section{Introduction}

Passenger transportation is one of the major branches of national economy aimed to satisfy the social needs of urban and regional population, therefore the study of problems associated with this area from theoretical and practical perspectives is of particular importance. In the presented paper the results obtained in the analytical study of passenger transportation by railway are considered.

The research made by the authors of the presented paper [1,2] allows them to define major criteria for evaluating the competitive ability of transport and passenger carriage services. They are mainly based on the evaluation of management and marketing systems activity. These problems were considered in several papers $[3,4]$. However, in the present work the emphasis is placed on determining the role of technological factors, which had not been analysed in the above-mentioned papers and other works $[5,6]$.

Hence, the present investigation is based on a thorough experimental study of passenger carriage by railway and on the original theoretical analysis. This research is particularly important because the theoretical analysis of the impact of technological factors on competitiveness is relevant for solving the problem of increasing the efficiency of the existing railway trans- portation system, and, especially, for the future development of Lithuanian railways.

\section{Major principles of the evaluation of the impact of technological factors}

In determining the impact of technological factors on the performance of the system of passenger carriage, the emphasis should be placed on competitive ability as a major criterion reflecting its effectiveness. The main assumption may be made that the system of passenger carriage by railway may be theoretically described in terms of an automatic control system. It has the inherent input and transformation units, output functions and feedback with all characteristic features. The goal is to establish the relationship between them and the efficiency characteristics of the above system, as well as its competitive ability.

In the present investigation the suggested evaluation criteria imply that general competitiveness of the system is expressed in terms of the vector $\bar{K}$ belonging to a set of vectors generally describing how effectively the system performs, i. e. $\bar{K} \in\left\{\bar{R}_{S}\right\}$. General competitiveness is, in turn, defined by a system of components (in a general case by $n$ components). Then, it may be written:

$$
\bar{K}=\overline{\mathrm{K}}\left[\overline{\mathrm{K}}_{1}, \bar{K}_{2}, \cdots, \bar{K}_{n}\right] .
$$


In fact the above components are the vectors of local competitive abilities. In considering them we assume that any competitiveness vector is determined by a set of sub vectors, i.e. by the influence vectors $\bar{X}_{i}$. Then a further analysis will be based on the identification of the relationships between local competitive abilities and the particular influencing factors.

Based on the research performed [7,8], major technological factors and the type of their relationships have been determined.

There are good reasons to assume that these are linear relationships implying that the problem of determining local competitiveness vectors may be appropriately formalized as well. The present investigation is based on a modified multiattribute analysis of influence, therefore, we will consider the following expression, i.e. a respective model of the local competitiveness vectors:

$$
\left.\begin{array}{c}
\bar{K}_{1}=A_{1} \bar{X}_{1}^{(1)}+B_{1} \bar{X}_{1}^{(2)}+\ldots+C_{1} \bar{X}_{1}^{(m)}+D_{1}(t) \\
\bar{K}_{2}=A_{2} \bar{X}_{2}^{(1)}+B_{2} \bar{X}_{2}^{(2)}+\ldots+C_{2} \bar{X}_{2}^{(m)}+D_{2}(t) \\
-------------\overline{-}-------\overline{-}---- \\
\bar{K}_{n}=A_{n} \bar{X}_{n}^{(1)}+B_{n} \bar{X}_{n}^{(2)}+\ldots+C_{n} \bar{X}_{n}^{(m)}+D_{n}(t)
\end{array}\right\}
$$

here $A_{1}, B_{1}, C_{1}$ - matrices of the relationship between the influence factors $1,2, m$ with parameters of local competitiveness $K_{1} ; A_{2}, B_{2}, C_{2}$ - matrices of the relationship between the influence factors $1,2, m$ with parameters of local competitiveness $K_{2} ; A_{n}, B_{n}, C_{n}$ - matrices of the relationship between the influence factors $1,2, m$ with parameters of local competitiveness $K_{n} ; D_{1}, D_{2}, D_{n}$ - matrices of free influence parameters.

It should be noted that the suggested model may also be applied to the analysis of a system having one of the local competitive abilities $K_{i}$, with a different expression of its relationship with the influence factors $X_{i}$. In this case a local competitiveness vector equation of the system (2) should be transformed without making any principal changes of the above system.

A description of an algorithm used to construct a formalized model of general competitiveness by defining local competitive abilities is given below. Here, two main components - infrastructure and rolling stocks - are considered.

Thus, the first local competitive ability of the system of passenger transportation by railway $\bar{K}_{1}$ is a competitive ability associated with a component of the infrastructure. Based on the above-mentioned analysis, the following major factors determining the value $\bar{K}_{1}$ were identified. They are the state $\bar{X}_{1}^{(1)}$ and the admissible speed $\bar{X}_{1}^{(2)}$. Then:

$$
\bar{K}_{1}=A_{1} \bar{X}_{1}^{(1)}+B_{1} \bar{X}_{1}^{(2)}+D_{1}(\tau) \text {. }
$$

A current state of Lithuanian railway infrastructure has been thoroughly analysed from technical, technological and organizational perspectives by K. Sakalauskas and Černiauskaitė [6], L. Lingaitis [4] and $\mathrm{V}$. Trumpa [9]. Therefore, in the presented paper this problem will not be considered at length.

As far as the admissible speed is concerned, it should be noted that because of poor roads the speed on national railways is low, not meeting the EU requirements. Therefore in order to increase the competitiveness of national railways the speed of trains should be increased to meet the European standards. This may be achieved by developing the whole infrastructure of national railways.

First, the locomotive speed should be increased in Kreta corridors:

- IXB - Vilnius-Klaipeda - up to $160-200 \mathrm{~km} / \mathrm{h}$,

- IXD - Kaišiadorys-Kybartai - up to $120 \mathrm{~km} / \mathrm{h}$,

- 1 - Mockava-Kaunas-Šiauliai - up to 160 $200 \mathrm{~km} / \mathrm{h}$.

The integration into the European high-speed railway network may help largely increase the competitive ability of Lithuanian railways. It may be achieved by constructing a high-speed railway line of the European standard in Kreta I railway [2, 10]. Superhigh speed railway line should connect Berlin with Helsinki via Warsaw, Šeštokai, Kaunas (or Vilnius), Šiauliai, Ryga, Tallinn, with a branch to St. Petersburg.

The construction of such an express railway would allow the competitive ability of the system of passenger by Lithuanian railways to be considerably increased. The superrailway would take over:

- from passenger carriage by air - more than $80 \%$ of the market on the routes to Warsaw and Riga; more than $50 \%$ - on the routes to Tallinn and $10-30 \%$ of the market on the routes to Berlin, Hamburg, Amsterdam and Paris;

- from passenger carriage by bus $-40-50 \%$ of the market on the routes to Riga and Warsaw and 60-90\% on the routes to Tallinn, Berlin, Hamburg, Amsterdam and Paris;

- from passenger carriage by individual automobiles $-15-30 \%$ of the market on the routes to Warsaw and Riga and 40-60\% on the routes to Berlin, Tallinn, etc.

The second local competitive ability of the system $\bar{K}_{2}$ is associated with a rolling stock component. Major factors determining the value $\bar{K}_{2}$ were found to be the quality of rolling stocks $\bar{X}_{2}^{(1)}$ and the admissible speed $\bar{X}_{2}^{(2)}$. Then,

$$
\bar{K}_{2}=A_{2} \bar{X}_{2}^{(1)}+B_{2} \bar{X}_{2}^{(2)}+D_{2}(\tau) \text {. }
$$

A problem of primary concern associated with keeping a competitive edge of Lithuanian railways is 
the renewal of passenger trains because they are old. Now, only $11 \%$ of cars out of 200 passenger cars have fewer than 10 years of service, while $39 \%$ are in service for 11 - 15 years. The service life of cars of all electric trains and D1 diesel locomotives exceed 15 years.

First, passenger trains on the route via IX Kreta corridor should be renewed, because the speed here may reach $160 \mathrm{~km} / \mathrm{h}$ according to plans. The trains on this route should be made up of new modern cars. This corridor is used by the train No 17120 „Baltija“ going from Vilnius to Klaipda, as well as „Pajk ris“ No 19/18 - on the route Vilnius - Klaipda and No 6/ 5 - on the route Kaunas - Moscow. Taking into account a $15 \%$ reserve and the expected increase of passenger flows on these routes five railway carriages with double-seat compartments, 35 compartment cars, 6 with compartments provided with radio stations, 6 restaurant cars, 24 sleeping cars and 73 passenger cars should be purchased. It may be recommended to buy passenger cars of various lay-out - with individual sections for passengers with children; for two passengers sitting vis-ą-vis at the table; for passengers with huge luggage, for smokers, etc. Such carriages are produced in Finland. In addition, when buying Finnish carriages, it is not necessary to pay for their adaptation to Russian standard tracks, which makes them cheaper.

It seems to be expedient to use motor cars instead of diesel locomotives on local not heavily loaded routes (up to $100 \mathrm{~km}$ ), which could reduce operational costs by up to 44 per cent. The calculations show that 6 motor cars could be used in Vilnius area, 4 in Diauliai and 2 in Kaunas and Klaipda regions [2].

By applying the theory of correlations we can get the following formal expression of general competitiveness (within the framework of the formulated problem, i.e. with respect to the components of infrastructure and rolling stocks):

$$
\bar{K}=p_{11} \bar{K}_{1}+p_{12} \bar{K}_{1}+p_{21} \bar{K}_{2}+p_{22} \bar{K}_{2},
$$

here $p_{11}$ and $p_{22}$ - the relationship parameters of local competitive abilities $\bar{K}_{1}$ and $\bar{K}_{2}$ and general competitiveness $\bar{K} ; p_{12}$ and $p_{21}$ - parameters of interrelationship between local competitive abilities $\bar{K}_{1}$ and $\bar{K}_{2}$.

Having obtained the above principal model, we may solve problems far beyond the scope of the competitiveness analysis of the particular cases (e.g. when new locomotives are purchased considering several offers from the competing firms, as well as deciding upon their routes) within the system of Lithuanian railways. A similar technique may be used to determine the comparative competitiveness of Latvian, Estonian and, partly, Finnish railways on the interna- tional route Via Baltica and its branch lines.

Developing the evaluation principles, the solution of an optimization problem of general competitiveness (conventionally referred to as technological) should be considered. In this case the methods presented in [1], allowing to seek for the maximum $\bar{K}$ value, may be applied. In fact, the maximum of the functional $I$ is sought according to:

$$
\max \mathrm{I}=\int_{t} F(K, \dot{K}, t) d t,
$$

here, $F(K, \dot{K}, t)$ - the function of competitiveness $K$ and its variation over time $t$ ( the value $\dot{K}$ ).

It may be recommended to adapt the algorithm of this problem to any particular problem having defined it within the limits outlined above.

\section{The analysis of system stability}

Let us now analyse the problems of the evaluation of the impact of technological factors from the perspectives of the general principles and the stability of passenger carriage by rail. This is connected with stability (or even critical) state when the particular technological procedures are implemented with respect to the considered components of infrastructure and rolling stocks.

The theoretical study made allows us to suggest an adapted composite three-component model for this case. It is of the form:

$$
\bar{R}(S) \rightarrow\left[R\left(\Delta S^{a}\right), R\left(\Delta S^{b}\right), R\left(\Delta S^{c}\right)\right] \frac{R(\Delta S)=1, \text { jei } \Delta S \geq 0}{R(\Delta S)=0, \text { jei } \Delta S<0},
$$

here $\bar{R}(S)$-stability criterion of system performance, describing the following stability modes: normal, when $R[1,1,1]$, non-stable, when $R[0,1,1]$ and critical, when $R[0,0,1] ; \Delta S^{a}$ - estimate of a particular haul (positive $-\Delta S^{a}>0$, zero $-\Delta S^{a}=0$ or negative $\left.\Delta S^{a}<0\right) ; \Delta S^{b}-$ evaluation stability of hauls in a month (positive $-\Delta S^{b}>0$, zero $-\Delta S^{b}=0$ or negative $\left.-\Delta S^{b}<0\right) ; \Delta S^{c}-$ general evaluation stability of route in a longer period of time (positive $-\Delta S^{c}>0$, zero $-\Delta S^{c}=0$ or negative $\left.-\Delta S^{c}<0\right)$.

If the state is found to be critical, i.e. $R[0,0,1]$, though not reaching a crisis point, a thorough stability analysis and the choice of actions to be taken to improve the situation are needed.

A detailed analysis may be based on a survey of passengers and examination of passenger flows. Recently some not profitable routes have been eliminated on Lithuanian railroads because the state does not subsidize local passenger carriage routes and their losses should be covered by the profit obtained from freight transportation by railway. However, not all the routes are provided with alternative bus transport. For 
example, passengers on the route Kaunas-Jonava have to walk $3-8 \mathrm{~km}$ to a bus station, implying that public transport is hardly available to them. This shows that detailed studies are necessary to make a proper decision about the expediency of means of transport and routes in order to avoid such situations.

Hence, to organize the effective passenger carriage by rail in this country a continuous study of the flows of passengers is needed. Such investigation should be made on major railway routes twice a year (in summer and in winter), while on minor routes it should be performed at the same time, but once in two years. The most accurate method based on calculations and a survey should be used for this purpose.

Optimizing passenger transportation the expectations and suggestions of passengers should be analysed from the questionnaires.

The experience has shown that the questionnaires are properly filled by more than $80 \%$ of passengers. In this way very important data on passenger transportation problems, organizational level of particular routes and essential drawbacks as well as about the purposes of travel, tickets bought, etc. can be stored. The above surveys are very popular in Western Europe. In Finland surveys of passengers are carried out twice a year on all railway routes (these are made alongside the studies of passenger flows), while in Holland a complex passenger survey is made once a year on all routes of all transport facilities.

For optimal organization of nationwide passenger carriage the following actions should be taken:

1) all local railway routes should be investigated in order to identify how many and what kinds of routes are needed in Lithuania;

2) based on the data obtained studying passenger flows and passenger survey it is necessary:

- to determine the required number of hauls on every route on weekdays,

- to differentiate trains on the route (slow - fast trains),

- to optimize train schedules,

- to coordinate train schedules on adjacent routes enabling the transfers of passengers (e.g. on the routes Vilnius - Kaunas and Kaunas - Marijampolè);

3) to make an agreement between the Public Service and the Government authorized institution (the best option would be the Ministry of Transport) subsidizing passenger carriage by railway (taking into account profitability as well);

4) to provide road transportation on the routes which are unprofitable for railway carriage;

5) it may be recommended to introduce 'railway plus bus' mixed transport on the routes VilniusKretinga- (Palanga- by bus) - Klaipèda and Vilnius - Marcinkonys - (Druskininkai - by bus);
6) it may be recommended to use fast local ,railway plus road" transport on the routes Vilnius - Kaunas, Kaunas - Klaipèda, Vilnius - Varèna, Vilnius Turmantas. The main passenger flows should be serviced by fast trains, while the schedules of local road transport (buses and vans) should match railway traffic to carry passengers over the region;

7) to organize nationwide passenger transportation by rail and by road on scientific grounds, one more principle should be introduced - a logical chain 'carriage plus transfer' should be implemented. This means that, based on research data, interurban train and bus traffic schedules and transfers from one route to another should be matched, as well as the abovementioned schedules of local bus routes and railway traffic.

The research made by J. Butkevičius [8] has shown that the prestige of public interurban passenger transport sharply dropped: as much as $81,3 \%$ of passengers use automobiles for travelling between the largest Lithuanian cities - Vilnius, Kaunas, Klaipeda and Šiauliai, while $14,9 \%$ of passengers travel by bus and only $3,8 \%$ of them go by train. Therefore, the implementation of complex recommendations suggested in the present work could largely improve passenger transportation by railway.

\section{Conclusions}

1. The system of passenger carriage by railway may be theoretically described in terms of an automatic control system because it has the inherent input and transformation units, output functions and feedback with all their characteristic features.

2. An algorithm for constructing a formalized competitiveness model is provided by defining local competitive abilities with respect to the units of a technological complex. The first local competitive ability of passenger transportation by railway is based on the component of infrastructure determined by its state and the admissible speed, while the second is the competitive ability based on the component referring to rolling stocks.

3. In order to increase the competitiveness of national railways the speed of locomotives should be increased to conform to the European standards, i.e. it should reach $120 \mathrm{~km} / \mathrm{h}$ on the routes Kaišiadorys Kybartai and Šiauliai - ̌̌ Sarkiai and $160-200 \mathrm{~km} / \mathrm{h}$ on the routes Vilnius - Klaipeda and Mockava - Kaunas - Šiauliai.

4. Besides, an important factor in raising competitiveness is the integration of Lithuanian railway into the European high-speed railway system constructing a high-speed European standard railway line in Kreta I corridor. 
5. Another important factor having a great impact on the comparative ability of railway was found to be the renewal of passenger rolling stocks. The emphasis is placed on the problem of replacing ordinary and diesel locomotives in corridor IX with motor cars on the local routes and routes with heavy traffic.

6. Since the Government does not practically subsidize unprofitable passenger transportation on the local routes, Lithuanian railways are forced to eliminate some of them. However, the alternative bus transport is not always provided, therefore, public transport is unavailable for the inhabitants of some regions. To avoid such critical situations it is recommended to use scientifically grounded methods suggested in the present work making decisions about the expediency of particular routes.

7. A number of actions which should be taken to increase the competitiveness of passenger transportation by rail are offered. Their implementation would also ensure a considerable increase of passenger flows carried by public transport as well as profit obtained from passenger transportation.

\section{References}

1. Žvirblis, A. The Principles of Analysis of Competitiveness and Control Schemes in Transport Services. Transport, Vol XVIII, No 2, Vilnius: Technika, 2003, p. 5760.

2. Butkevičius, J. The passenger transportation (Keleivių vežimai). Vilnius: Technika, 2002. 416 p. (in Lithuanian).
3. Friesz, T.; Bernstein, D.; Stough, R. Dynamic Systems. Variational inequalities and control theoretic models for predicting time - varging urban network flows. Transportation Science, 1996, Vol 30, p. 14-31.

4. Lingaitis, L. P. The future of railways. Lithuanian railways (Lietuvos geležinkeliai), No 1, 2002, p. 56-61 (in Lithuanian).

5. Toth, P.; Vigo, G. Heuristic algorithmus for the handicapped persons transportation problem. Transportation Science, 1997, Vol 31, p. 60-71.

6. Černiauskaite, L.; Sakalauskas, K. Technical and economical problems of integration of IX B and IX D international railway transport corridors into european railway transport network. Transport, Vol XVIII, No 4, Vilnius: Technika, 2003, p. 143-152.

7. Mazūra, M. Prediction of Major Trends of Transportation Development. Transport, Vol XVII, No 2, Vilnius: Technika, 2002, p. 57-59.

8. Butkevičius, J. The implementation of new carriage technologies in the Lithuanian railway transport and establishment of the prospective markets for railway and road transport. Transport, Vol XVIII, No 4, Vilnius: Technika, 2003, p. 168-173.

9. Trumpa, V. S. Transport corridors and the perspectives of their development. Lithuanian railways (Lietuvos geležinkeliai), No 1, 2002, p. 16-22 (in Lithuanian).

10. Butkevičius, J.; Baublys A. The development of freight and passenger transportation by railway across the Lithuanian/Polish border. In: Humanisation in technology (Technikos humanizavimas). Vilnius: Technika, 2001, p. 31-35 (in Lithuanian). 